\title{
INNOVATIVE VISUALIZATION SYSTEM DESIGNED TO MONITOR PARAMETERS OF MINING SYSTEMS OPERATION
}

doi:10.2478/mape-2018-0046

Date of submission of the article to the Editor: 04/2018 Date of acceptance of the article by the Editor: 07/2018
MAPE 2018, volume 1, issue 1, pp. 361-368

\section{Dr inż. Dawid Szurgacz}

Center of Hydraulics DOH Ltd, Poland

Dr hab. inż. Jarosław Brodny

Silesian University of Technology, Poland

\begin{abstract}
Mining machines suitable for hard coal mining, due to the specifics of this industry must be characterized by very high technical parameters. In particular, it concerns their durability, reliability and availability. Currently used machines approved for operation in underground conditions meet such requirements. Nevertheless, during their operation it is reasonable to conduct supervision and control of work parameters. This applies to both machine manufacturers and users, which is especially important in the event of a failure. Mine employees should be able control of the entire operation process. This control can be effective thanks to a visualization system developed to monitor the working parameters of mining systems. The paper discusses the innovative system and presents the results of efficiency tests. They concerned the visualization of the operation of a powered roof support. The obtained results indicate that the assumed goal of the system has been achieved. The system is built on elements of industrial automation, which guarantees the reliability of the indicated values. Its graphic layout and selection of the presented parameters are also approved. It should also be emphasized that the system can work with currently operating systems and is easy to expand. According to the Authors, the system should find a wide application in practice.
\end{abstract}

Keywords: powered longwall system, powered roof support, control system, working parameters visualization.

\section{INTRODUCTION}

The use of innovative technical solutions is a key element of the process of hard coal production (Brodny et al., 2017; Brodny and Tutak, 2018; Stecuła et al., 2017; Szurgacz and Brodny, 2017) . Primarily, these solutions include all kinds of equipment and machines used in the process of mining, horizontal and vertical transport. An important element of the system is a powered roof support which must fulfil a number of tasks (Horyl et al., 2017; Szurgacz and Brodny, 2017). It is also used to stabilize the work of the shearer and longwall conveyor. It can therefore be assumed that such support is a base thanks to which the entire longwall system can operate. For this reason, it is important to properly match the roof support to the mining and geological conditions. The support can operate properly only if the parameters are being constantly monitored with means of elements of industrial automation such as sensors, transducers, recorders and various other types of equipment (Brodny et al., 2017). Similar requirements concern all components, machines and devices of the powered longwall system. Monitoring the operation of these machines based on intelligent solutions guarantees maintaining a high level of their work, which in the case of mining translates into an increase in the concentration of extraction and increased safety at work (Brodny and Tutak, 2017a; Brodny and Tutak, 2017b; Tutak and Brodny, 2017). It is also important due to the fact that Polish mining is entirely based on the operation of longwall systems in which there are many 
natural hazards (Tutak, 2017a; Tutak, 2017b). Consequently, machines and devices included in the longwall system should be characterized by high durability and reliability.

In order to make an effective assessment of the work of a powered longwall system, it is necessary to obtain data and information about its operation. This particularly refers to the technical parameters of the operation of individual machines. In order for the obtained data to be reliable, it is necessary to apply archiving and visualization of modern information and communication systems (Kwiecień, 2013; Zhang et al., 2014). The new visualization system designed to monitor the operation of longwall machines presented in this publication, has all required features. Its task is to monitor the operation of the longwall system and provide recorded data. The appropriate selection of methods to signal the technical condition of individual machines and the indication of places or parameters that may pose a threat to its operation significantly impacts on the safety level (Dylong, 2013; Krzystanek et al., 2004). The introduction of such a system to monitor the operation of machines should lead to a reduction in the costs of unplanned stops of individual machines and the entire complex. The presented system together with the set of tests should be widely used in practice. In particular, it should become an important tool supporting the process of managing a machinery park. The acquired information, especially cocnerning critical states of machines should be a source of knowledge provided to the maintenance services responsible of conducting optimization activities in the field of operation of facilities and technical systems.

The paper presents only a part of the visualization possibilities of the developed tool in relation to the powered roof support. The universality of the system makes it possible to connect all machines of the complex and other devices, ultimately all machines involved in the coal production process.

According to the Authors, the presented tool together with the results of the conducted simulations, creates great opportunities for practical application in the mining industry. The use of this type of software should improve the efficiency of the production process and its safety.

\section{METHODOLOGY OF RESEARCH}

When developing the presented visualization system, particular attention was paid to the simplicity and speed of the communication system and its functionality (Boyer, 2009; Bostad, 2012). In the case of a powered roof support, the basic source of information is data from individual sections taken from the electrohydraulic control system. Then, such data is sent via fibre optic link, possibly via an Ethernet cable, to the visualization system. The refresh rate of data was assumed at only $1 \mathrm{~Hz}$. With large complex systems or difficult operating conditions, the data refresh time can be extended to the time necessary to correctly transmit data on the communication line. The visualization program displays the current status of all machines and individual sections in the longwall. Figure 1 presents the communication system of the powered roof support.

The work of the powered roof support includes a number of complex operations. This is due to the fact that it works periodically. Technical operations on the section last no longer than a minute, and for the remaining time the section is not operated. Some values remain virtually unchanged at that time, while others change slowly, which is included in the diagram shown in Figure 1.

Data from the system may also be transmitted irregularly or incompletely due to power off in the longwall, controller or power supply failure, mechanical interruption of the communication interface, etc. For this reason, the database was designed to record all data that can later be recreated in an off-line system. 


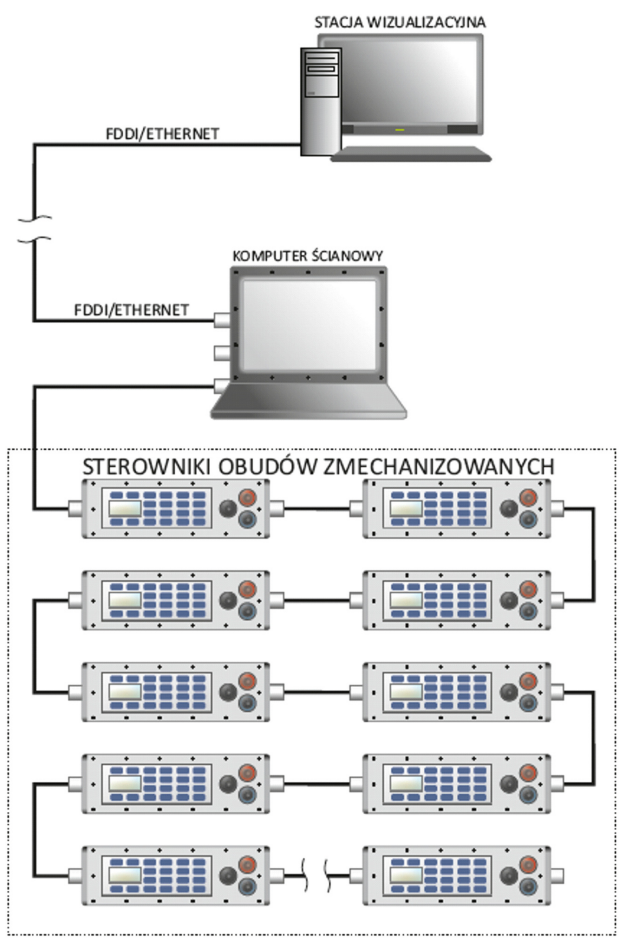

Fig. 1. Diagram of the communication system of the powered roof support sections

The obtained data will be used (in addition to visualization) also for creating reports on roof support parameters, diagnostics of some elements of the section, generating two- and threedimensional charts, etc. Therefore, it will be possible to view data according to various criteria - which is also included in the developed system. Due to the need (in some cases) to analyse the data over a longer period, the data will be stored and archived. The applied software was based on Windows Embedded 8 (longwall system), Windows 10 Pro (central computer) and database server MS SQL Express 2016.

\section{RESULTS}

For the purpose of conducting tests of the program, a simulation of the powered roof support unit was performed in LabView environment in order to check the visualization system.

Figure 2 shows the testing station where the tests were carried out. The simulator is presented on monitor No. 1 to visualize the work of the section, the monitor no. 2 displays a program to visualize the process, the monitor no. 3 shows the preview the calculation algorithm.

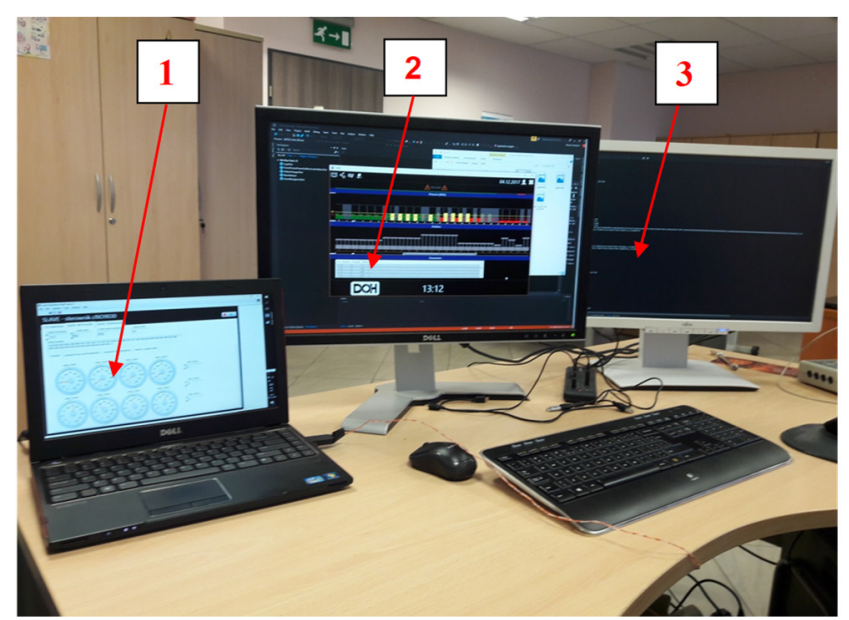

Fig. 2. Testing station for the visualization system 
The simulator was used to test the entire program and individual phases of the unit's work. Control data was sent from controllers related to individual roof support sections (paired section and driver numbers, respectively). Based on the obtained results, system tests were carried out. Figure 3 shows the controller with data for an exemplary roof support section, while Figure 4 shows the view of the registered pressure values in individual hydraulic systems of the section.

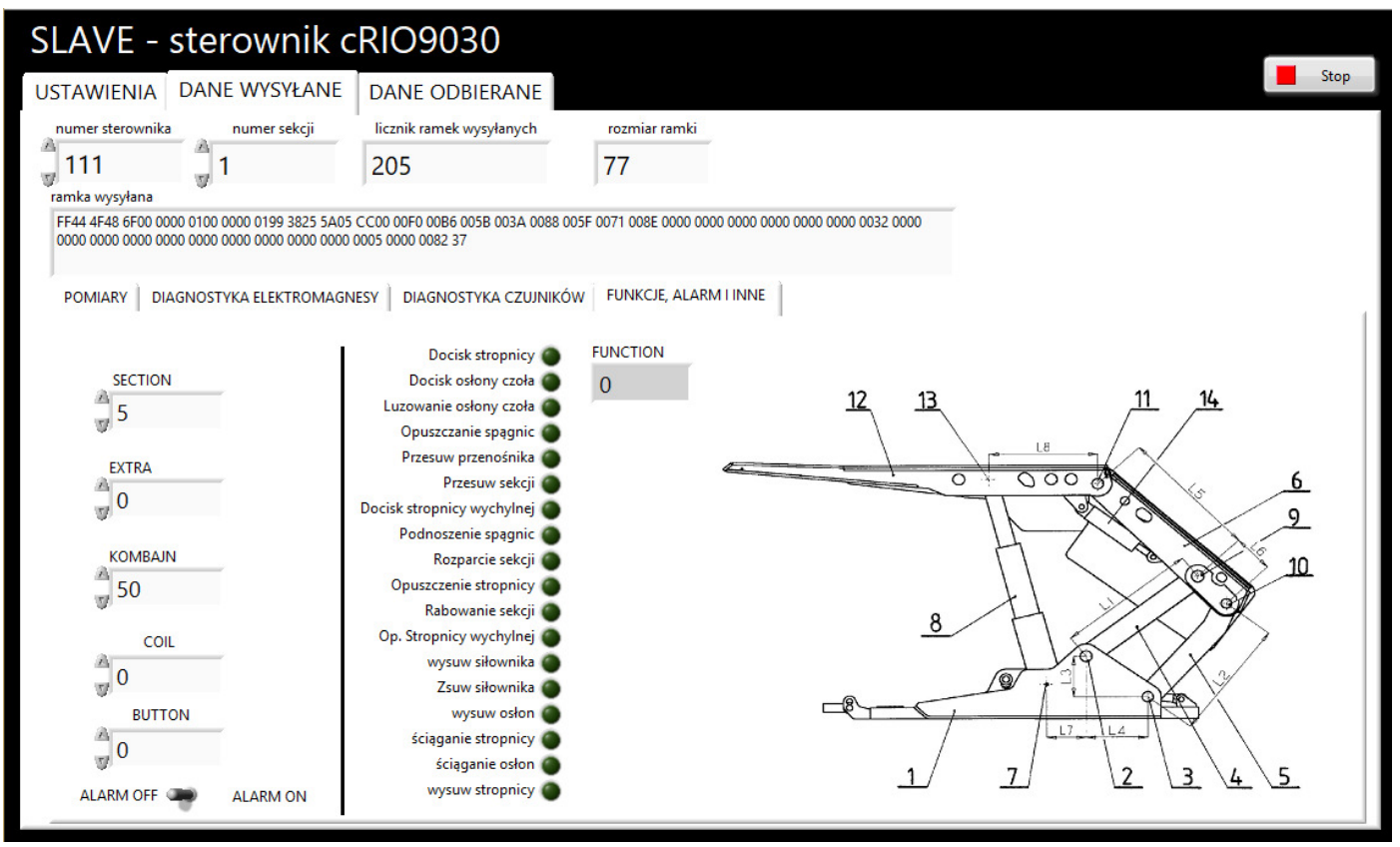

Fig. 3. Data controller monitoring the powered roof support operation

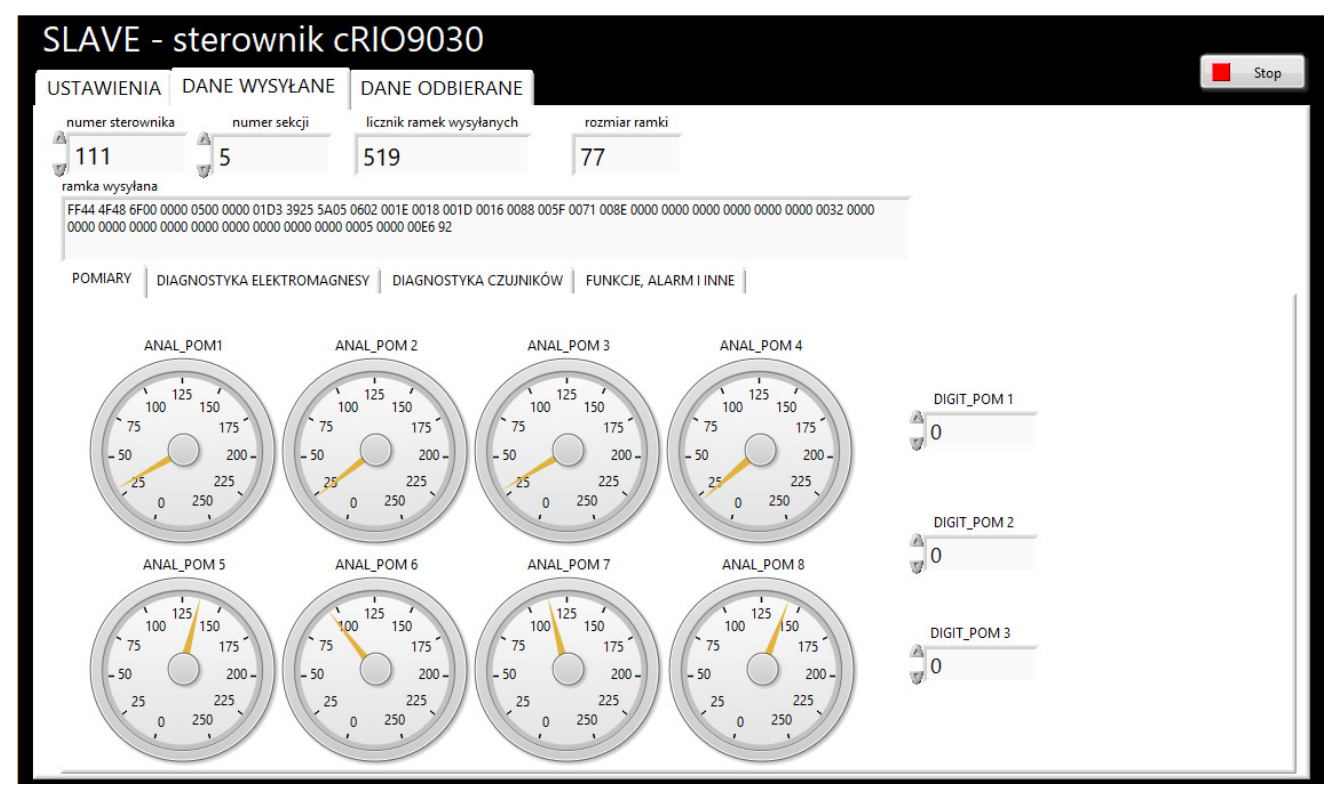

Fig. 4. Visualization of recorded pressure values for section No. 5

Figure 5 shows the view of the diagnostic data file sent for the sample pressure sensor. Figure 6 presents the diagnostic data file of the solenoid valves. 


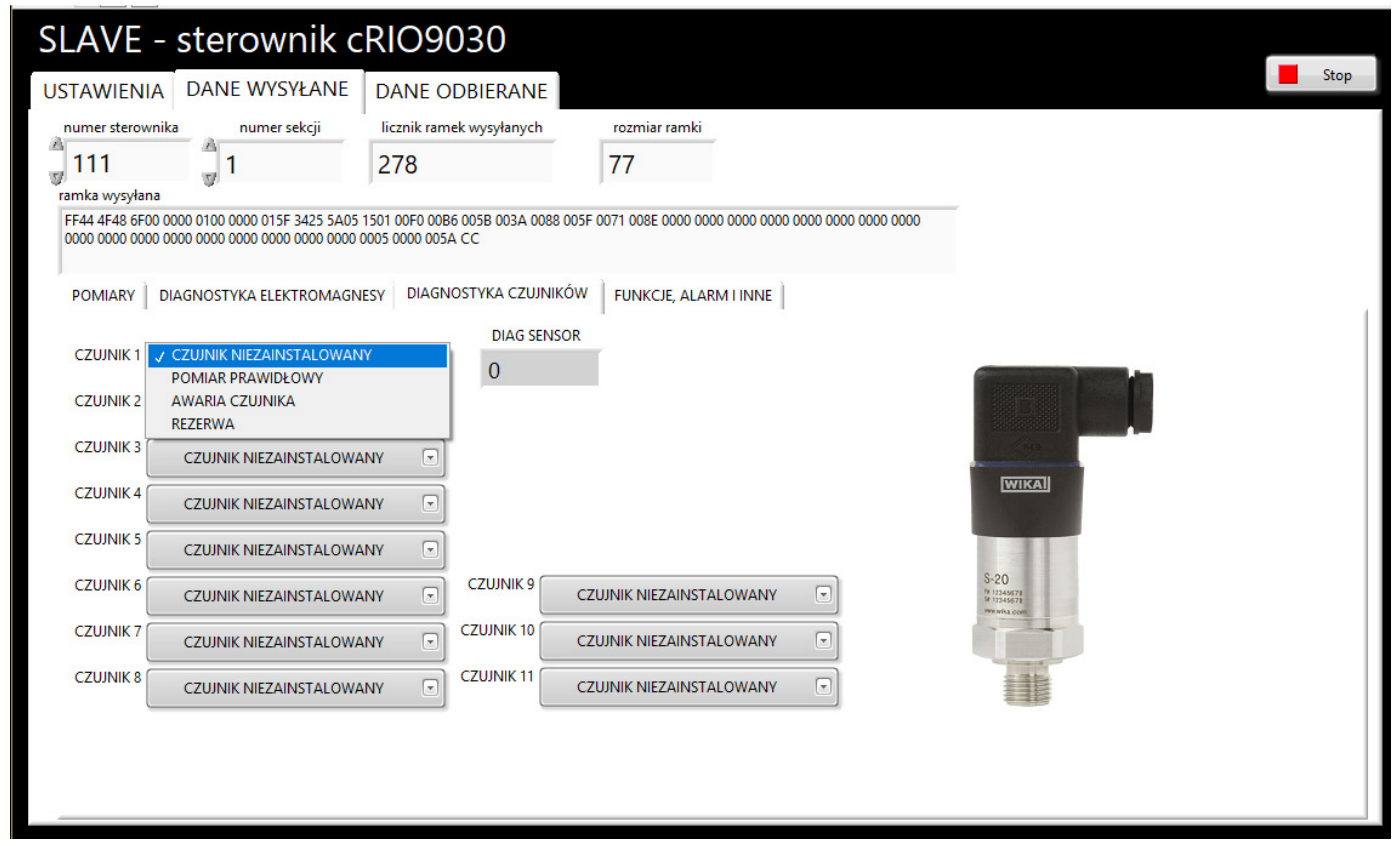

Fig. 5. Uploaded diagnostic data file for the pressure sensor

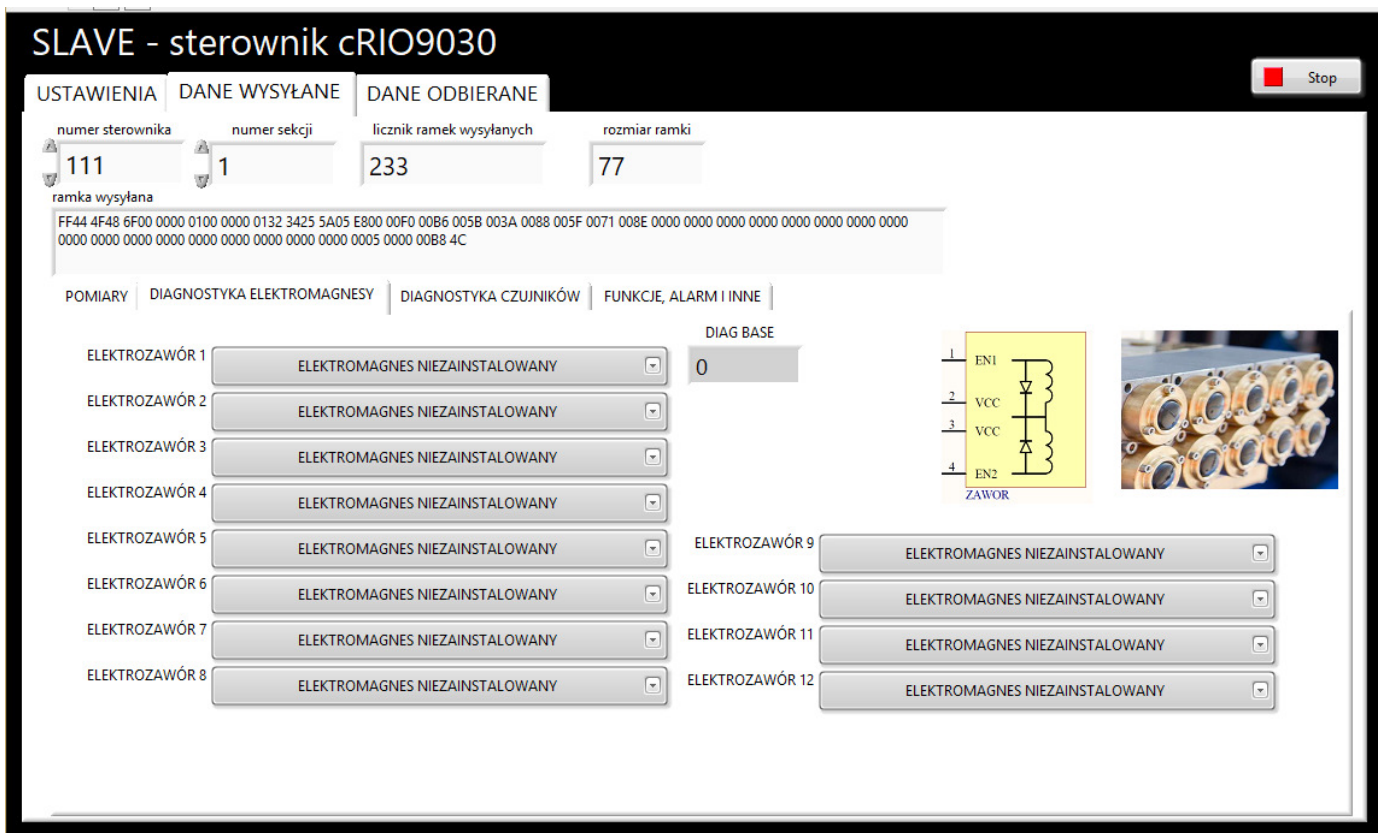

Fig. 6. Files of diagnostic data of solenoid valves being sent

The main goal of the research was to test the entire visualization system and its individual components. The visualization system for the entire longwall with a visible shearer is shown in Figure 7. 


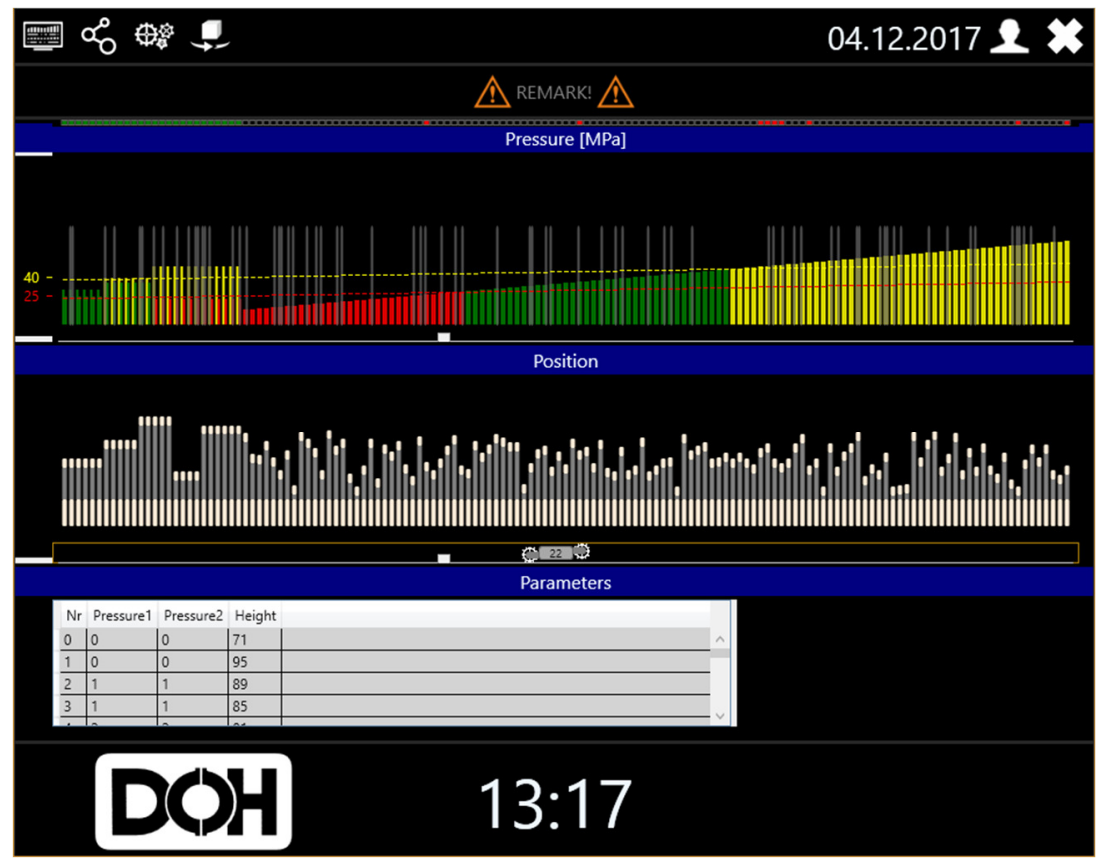

Fig. 7. The visualization system for the entire longwall with a visible shearer

Figure 8 shows a fragment of the visualization system monitoring the working state of the powered roof support. Each registered and visible parameters of the operation are numbered respectively. The following system of pressure markings was adopted for the presented system:

- from 0 to $25 \mathrm{MPa}$ in red (1),

- from 25 to $40 \mathrm{MPa}$ in green (2),

- above $40 \mathrm{MPa}$ in yellow (3).

The next presented elements include:

- height of the position section (4),

- location of the shearer in the longwall (5),

- no communication with the section controller (grey, 6),

- work of a longwall conveyor (yellow, 7).

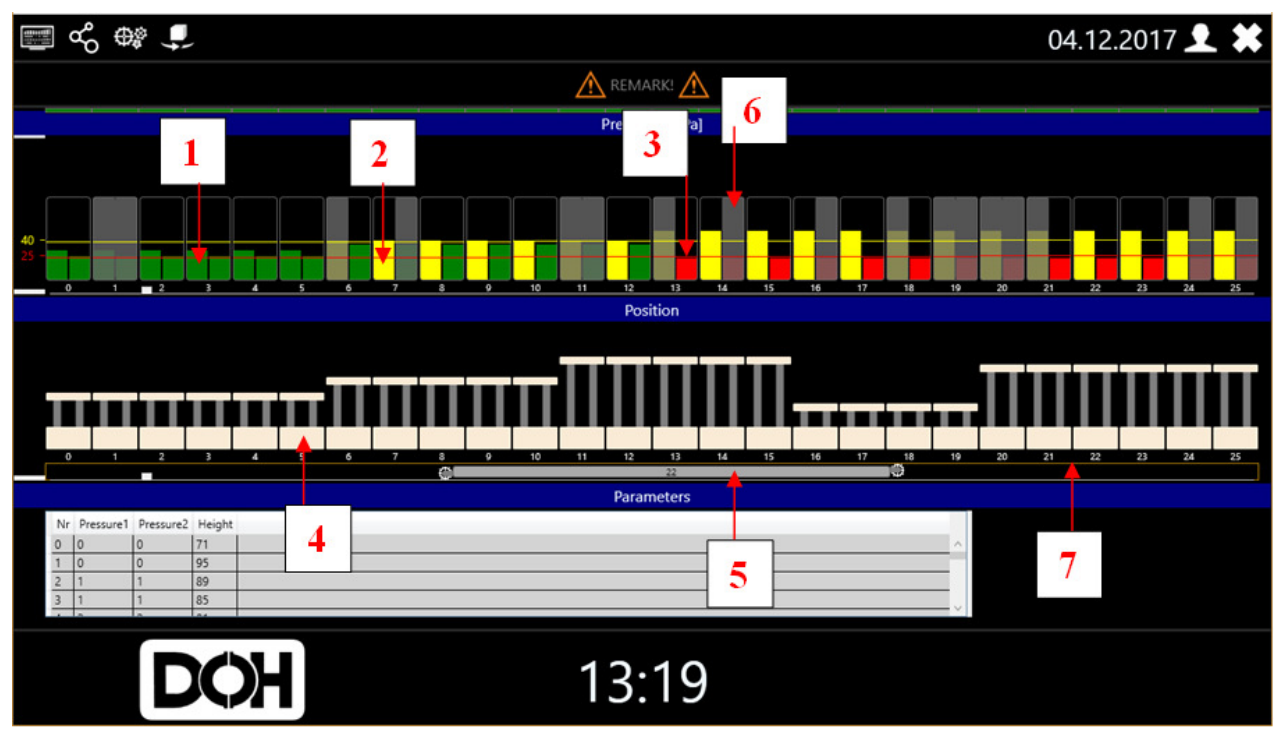

Fig. 8. A fragment of the visualization system with marked work parameters 


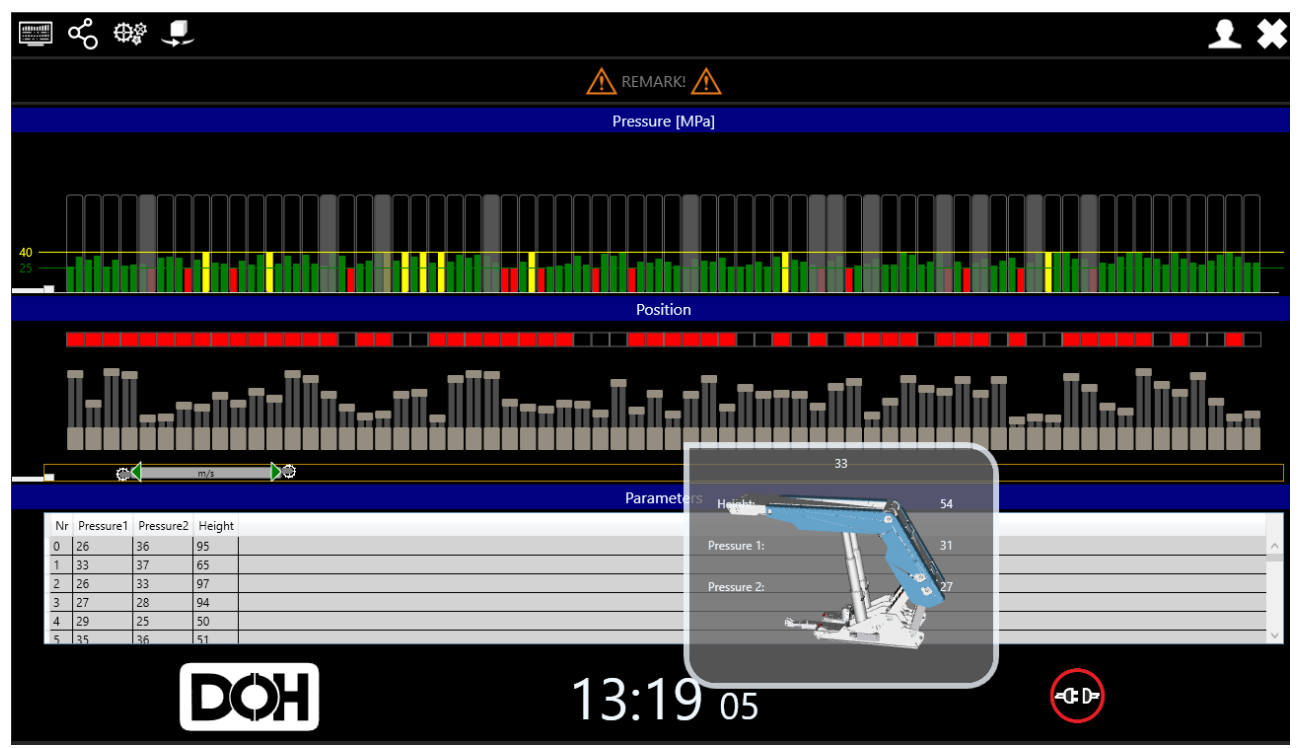

Fig. 9. Section view in 3D after clicking the mouse

The developed system also enables the display of individual machines and devices monitored by the system. The preview of the work parameters of the selected section along with its schematic in the spatial layout (3D) is shown in Figure 9.

\section{CONCLUSION}

Visualization of the technological process in the mining exploitation process is crucial for the maintenance services and the efficiency of the entire production process. Easy access to the work parameters of individual machines allows to control their condition and monitor the values of these parameters. At the same time, the reliability of the presented data is significant as well as the sensors used, and the entire data transmission system. The presented solution is based on data obtained from the industrial automation system which guarantees the quality of the data obtained. The developed graphical data presentation system is currently being tested both in terms of their quality and quantity as well as availability by dispatchers. The Authors depend on the development of a user-friendly visualization system, and at the same time containing the necessary data for the assessment and diagnostics of the condition of the tested machines. The system tests carried out confirm the validity of the adopted assumptions. In particular, this applies to the selection of data for visualization and the graphic layout of the system. The developed system should be ready to be applied in underground conditions in the nearest future. It should greatly facilitate the work of dispatchers and allow very quick and easy access to reliable data on the parameters of the machines. This, in turn, should improve the safety of mining processes.

\section{ACKNOWLEDGEMENTS}

The work was carried out within the project 'Innovative electrohydraulic control system for powered roof support'. POIR. 01.01.01-00-1129/15. The Operational Programme Smart Growth 2014-2020 carried out by the National Centre for Research and Development.

\section{REFERENCES}

Bolstad, P. (2012). GIS Fundamentals: A First Text on Geographic Information Systems. XanEdu Publishing Inc.

Boyer, S. (2009). Scada. Supervisory Control And Data Acquisition. ISA: The Instrumentation, Systems, and Automation Society.

Brodny, J. and Tutak M. (2018). Use of IT platform in determination of efficiency of mining ma-chines. E3S Web Conferences Volume 29, 2018, E3S Web of Conferences elSSN: 2267-1242 Copyright/Published by: EDP Sciences; https://doi.org/10.1051/e3sconf/20182900014. 
Brodny, J., Alszer, S., Krystek, J. and Tutak, M. (2017a) Availability analysis of selected mining machinery. Archives of Control Sciences Volume 27(LXIII), 2017. No. 2, pages 197-209, 2017. DOI : 10.1515/acsc-2017-0012.

Brodny, J. and Tutak, M. (2016a). Determination of the zone endangered by methane explosion in goaf with caving of operating longwalls. SGEM 2016 Conference Proceedings, Book1 Vol. 2, 299-306 pp. DOI: 10.5593/SGEM2016/B12/S03.039.

Brodny, J. and Tutak, M. (2016b). The impact of the flow volume flow ventilation to the location of the special hazard spontaneous fire zone in goaf with caving of operating longwalls. SGEM 2016 Conference Proceedings, Book1 Vol. 2, pp. 897-904, DOI: 10.5593/SGEM2016/B12/S03.115.

Dylong, A. (2013). System dyspozytorski THOR - nowa jakość w zakresie wizualizacji pracy i bezpieczeństwa zakładu górniczego. Szkoła Eksploatacji Podziemnej, pp. 67-74.

Horyl, P., Sňupárek, R., Maršálek, P. and Pacześniowski, K. (2017). Simulation of laboratory tests of steel arch support. Arch. Min. Sci. 62, 1, 163-176.

Krzystanek, Z., Dylong, A. and Wojtas, P. (2004). Monitorowanie parametrów środowiska w kopalni system SMP-NT. Mechanizacja i Automatyzacja Górnictwa, (9).

Kwiecień, R. (2013). Komputerowe systemy automatyki przemysłowej. Helion.

Stecuła, K., Tutak, M. and Brodny, J. (2017). Application of chosen elements from Japanese production and maintenance management philosophies in polish coal mines. 17th International Multidisciplinary Scientific Geoconference SGEM 2017. pp. 93-100. DOI: doi.org/10.5593/sgem2017/13.

Szurgacz, D., Brodny, J. (2017). An innovative system to test components of mining machinery control hydraulics. 17th International multidisciplinary scientific geoconference SGEM 2017, Volume 17. Science and technologies in geology, Exploration and Mining Issue 13. pp. 47-54, doi.org/10.5593/sgem2017/13/S03.007.

Tutak, M. and Brodny, J. (2017b) Determination of Particular Endogenous Fires Hazard Zones in Goaf with Caving of Longwall. IOP Conf. Series: Earth and Environmental Science 95, 042026 doi:10.1088/1755-1315/95/4/042026.

Tutak, M. (2017a). Analysis of varying levels of methane emissions from coal mines in Poland. SGEM2017 Vienna GREEN Conference Proceedings, ISBN 978-619-7408-28-7 / ISSN 13142704, 27 - 29 November, 2017, Vol. 17, Issue 43, 301-308 pp; DOI: 10.5593/sgem2017H/43/S19.038.

Tutak, M. (2017b). Assessment of hydrodynamics of gas flow through the porous rock structures. 17th International Multidisciplinary Scientific GeoConference SGEM 2017, SGEM2017 Vienna GREEN Conference Proceedings, ISBN 978-619-7408-26-3 / ISSN 1314-2704, 27 - 29 November, 2017, Vol. 17, Issue 15, 53-60 pp; DOI: 10.5593/sgem2017H/15/S06.007.

Zhang, Y., Wei, Y., Dongsheng, H. and Young-II, K. (2014). An Integrated Environment Monitoring System for Underground Coal Mines-Wireless Sensor Network Subsystem with Multi-Parameter Monitoring. Sensors, 14, pp. 13149-13170; doi:10.3390/s140713149 